\title{
Does corporate social responsibility affect the cost of equity in controversial industry sectors?
}

\author{
Abdelmajid Hmaittane \\ National School of Trade \& Management (ENCG), Ibn Zohr University, Agadir, Morocco \\ E-mail address: a.hmaittane@uiz.ac.ma \\ Full postal address: B.P 37/S Hay Salam, Agadir, Morocco
}

\begin{abstract}
Kais Bouslah
Centre for Responsible Banking \& Finance, School of Management, University of St Andrews, Scotland, UK

E-mail address: kbhb@st-andrews.ac.uk

Full postal address: School of Management, University of St Andrews

Gateway Building, North Haugh, St Andrews KY16 9RJ, UK
\end{abstract}

\section{Bouchra M'Zali}

AICRI, CRSDD-ESG-UQAM, Université du Québec à Montréal, Montreal, Canada E-mail address: mzali.bouchra@uqam.ca

Full postal address: Département Stratégie des affaires, ESG-UQAM

315 Rue Sainte-Catherine E, Montréal, QC H2X 3X2, Canada 


\section{Does corporate social responsibility affect the cost of equity in controversial industry sectors?}

Purpose - This study examines whether corporate social responsibility influences the cost of equity capital of firms operating controversial industry sectors.

Design/methodology/approach - This paper computes the ex-ante cost of equity capital implied in analyst earnings forecasts and stock prices for a sample of 2,006 U.S. firm-year observations belonging to controversial industry sectors (alcohol, tobacco, gambling, military, firearms, nuclear power, oil and gas, cement and biotechnology) during the period 1991-2012. The baseline regression model links CSR score to the implied cost of equity capital (ICC) and controls for firmspecific characteristics, industry factors, and economic or market-wide factors. This model enables to capture the differential effect of CSR on ICC when the firm belongs to a specific sector of the controversial industries by adding an interaction term between CSR and the dummy variable representing this belonging.

Findings - The findings show two main results. First, CSR engagement significantly reduces the implied cost of equity capital (ICC) in all controversial industry sectors, taken as a group, as well as in each one of these sectors individually. Second, this effect is more pronounced when the firm belongs to the alcohol and tobacco industry sectors.

Research limitations/implications - T

The findings have two important practical implications. First, they should increase managers' confidence and incentives, in controversial industry sectors, to pursue CSR activities. Second, policymakers can encourage managers to undertake CSR initiatives in controversial industry sectors through tax incentives (e.g., reduce taxes for CSR related investment projects).

\section{Originality/value -}

This paper extends prior studies that investigate the perceptions of capital market participants of firm's CSR commitment (e.g., Sharfman and Fernando, 2008; Goss and Roberts, 2011; El Ghoul et al., 2011; Jo and Na, 2012; Bouslah et al., 2013) by examining the effect of CSR on ICC in the controversial industry sectors. It contributes to the debate around the relevance of CSR in controversial sectors by providing evidence of the reduction effect of CSR activities on ICC in controversial industries and by showing that this reduction impact is more pronounced when the firm belongs to alcohol, tobacco industry sectors.

Keywords Corporate Social Responsibility; Cost of equity capital; Controversial industry sectors JEL classification: G32; G34; M14 


\section{Does corporate social responsibility affect the cost of equity in controversial industry sectors?}

\section{Introduction}

Over the last decades, business corporations have devoted considerable and increasing investments to corporate social responsibility (hereafter CSR) activities in response to tremendous pressures coming from their stakeholders including shareholders ${ }^{1}$. Virtually all types of corporation have become more active in CSR domains, including those corporations belonging to controversial industries -that may be polemic owing to the goods or services that they provide and/or how they conduct themselves in the process of doing business (Du and Vieira, 2012)-. The involvement in CSR programs by firms belonging to controversial industries could be perceived as contradictory by their stakeholders because the core business of these firms can be perceived as socially and environmentally controversial and undesirable. The direct consequence of this stakeholders' perception lead to question the benefits of CSR investments in the case of firms belonging to controversial industries.

To illustrate this context, consider the case of firms operating in the oil and gas industry. By its nature, this industry' operations involve many potential negative environmental and social effects, including land clearance, oil spills, natural gas emissions and problems with local communities (Frynas, 2009). However, over the years and at the sector level, important and noteworthy environmental improvements have taken place such as the decrease in the number and the volume of oil spills. ${ }^{2}$ At the firm level, significant improvements have been done or initiated such as gas emissions reduction, investments in renewable energy alternatives, community development programs aiming to build schools and hospitals, launch of micro-credit schemes for local people aiming to assist youth employment projects, particularly in developing countries (Frynas, 2009). While not all oil and gas firms are engaged in CSR activities with the same level of effort, some firms have been recognised as leaders in corporate citizenship worldwide and some are doing relatively little and it is important to know how the investor evaluates such differences in CSR engagement.

In this paper, the focus is on the investor perception through the investigation of how CSR initiatives of firms in controversial industry sectors affect their cost of equity capital. In particular, we argue that CSR activities undertaken by a firm belonging to the controversial industry sectors reduce the required risk premium of holding its stock and therefore its cost of equity. This is because of the risk mitigation effect associated with CSR activities. Three theoretical arguments could explain the risk mitigation effect of CSR. The first argument lies on the investor perception that CSR involvement directly decreases firm' risk. For instance, social responsibility enables firms to reduce the probability that they will face social and/or environmental crisis implying higher cash outflows such as costly government imposed fines and clean-up costs. By avoiding those future negative cash flows, CSR commitment reduces firm's risk exposure (Godfrey, 2005;

\footnotetext{
${ }^{1}$ According to US SIF Foundation (2016), the value of the total assets engaged in sustainable, responsible and impact investing practices at the start of 2016 is $\$ 8.72$ trillion, which represents nearly 22 percent of the $\$ 40.3$ trillion in total assets under professional management in the United States.

${ }^{2}$ According to Frynas (2009), the number of large oil spills (above 700 tonnes) caused by oil tankers and other vessels has dramatically decreased from 25.2 spills per year in the period 1970-1979 to 3.6 spills per year in the period 2000-2007.
} 
El Ghoul et al., 2011) and consequently will decrease its cost of equity capital. The second argument suggests that CSR reduces asymmetric information. CSR signals the quality of management to investors (Akpinar et al., 2008), and as such it decreases the monitoring and auditing costs. The third argument stipulates that socially conscious investors will avoid stocks of firms with poor CSR and as a result, their shareholder base will be reduced (Hong and Kacperczyk, 2009). This reduction translates in a limited risk sharing opportunities and therefore lower stock prices and higher cost of equity capital.

This paper also argues that the effect of CSR activities on firm' cost of equity capital is different depending on the controversial industry sector. There is an important heterogeneity within the controversial industry sectors. On one hand, the so-called "sinful" industries, e.g., alcohol, tobacco, and gambling are described as "controversial" based on social norms (Lindgreen et al., 2012). On the other hand, some industries are described as "controversial" due to the externalities (i.e., environmental, social, governance or ethical issues) generated by the nature of their activities, e.g., military, firearms, nuclear power, oil and gas, cement and biotechnology (Lindgreen et al., 2012; Cai et al., 2012). This difference might affect how the investor perceive and assess the value CSR actions.

There are few studies that examine the impact of CSR on the cost of equity capital (e.g., Sharfman and Fernando, 2008; El Ghoul et al., 2011). Also, studies that explore how CSR activities impact corporate financial performance in the context of the controversial industry sectors are scarce (Hong and Kacperczyk, 2009; Cai et al., 2012; Jo and Na, 2012; Rodrigo and al., 2016). To the best of our knowledge, the impact of CSR on the cost of equity capital of firms belonging to the controversial industry sectors (alcohol, tobacco, gambling, military, firearms, nuclear power, oil and gas, cement and biotechnology) has not been examined. Consequently, this paper tries to fill this gap. A key to understand the contribution of this work is the distinction between firms in controversial industry sectors (i.e., the main business of the firm is controversial) and firms that are only involved somehow in controversial business issues (i.e., the main business of the firm is non-controversial). ${ }^{3}$ For instance, Starbucks Corporation, which is a coffee company and a coffeehouse chain belonging to the retail-eating places industry (a non-controversial business), is also involved in some activities related to alcohol which is a controversial business. 4 This study does not include such companies.

We test our hypotheses using a sample of 2,006 firm-year observations belonging to controversial industry sectors covering the period from 1991 to 2012. Following previous studies, e.g., Dhaliwal et al. (2006), Hail and Leuz (2006) and El Ghoul et al. (2011), we compute the ex-ante cost of equity implied in analyst earnings forecasts and stock prices (ICC hereafter). In addition, we follow Jo and $\mathrm{Na}$ (2012) to assign firms to controversial industry sectors.

\footnotetext{
${ }^{3}$ The work of El Ghoul et al. (2011) has explored how firm's participation to controversial business issues, not CSR, affects this cost. To measure this firm's participation, the authors used dummy variables based on six MSCI ESG KLD exclusionary screens (alcohol, gambling, tobacco, military, firearms and nuclear power). For each company covered, KLD database indicates whether the company is involved in controversial business issues as indicated by the screens. This implies that these screens capture both firms in controversial industry sectors (i.e., the main business of the firm is controversial) as well as those firms that are only involved somehow in controversial business issues (i.e., the main business of the firm is noncontroversial).

${ }^{4}$ According to the Standard Industrial Classification, Starbucks corporation belongs to the retail-eating places industry (SIC code 5812).
} 
Our findings show two main results. First, CSR engagement significantly reduces the implied cost of equity capital (ICC) in all controversial industry sectors, taken as a group, as well as in each one of these sectors individually. Second, this effect is more pronounced when the firm belongs to the alcohol and tobacco industry sectors.

This work contributes to the literature in different ways. First, it extends prior studies that investigate the perceptions of capital market participants of firm's CSR commitment (e.g., Sharfman and Fernando, 2008; Goss and Roberts, 2011; El Ghoul et al., 2011; Jo and Na, 2012; Bouslah et al., 2013) by examining the effect of CSR on ICC in the controversial industry sectors. Second, it extends those few studies that examine how CSR activities impact corporate financial performance in the context of the controversial industry sectors (Cai et al., 2012, and Jo and Na, 2012). Third, it contributes to the debate around the relevance of CSR in controversial sectors by providing evidence of the reduction effect of CSR activities on ICC in controversial industries and by showing that this reduction impact is more pronounced when the firm belongs to alcohol, tobacco industry sectors.

The remainder of this paper is organized as follows. In the second section, we discuss the corporate social responsibility in controversial industry sectors and its link to the cost of equity capital. In the third section, we describe our sample and data, and define our models and variables. We present and analyze our results in the fourth and fifth sections. We conclude in the sixth section.

\section{Literature review and hypotheses development}

Although over the years corporate social responsibility commitment has become more widespread and continuously increasing among almost all types of firms, its financial outcomes remain an open question. Theoretically as well as empirically, there is no consensus yet on the effect of CSR activities on firm's value and performance even though more and more studies show that the link is more likely positive (e.g., Margolis et al., 2007). In controversial industry sectors, the problem is more acute since there is a doubt and skepticism toward the core business of these firms and its adequation with CSR actions. Beyond the debate on the legitimacy of firms in such industry sectors to engage CSR initiatives ${ }^{5}$, our interest is in the financial relevance of such investments and in particular to know how the investor (stockholder) perceive them through the implied cost of equity capital. In the following section, we explain how theoretically, from a finance stand point, CSR can affect the firm' cost of equity capital in controversial industry sectors.

The cost of equity capital of a firm is the rate of return investors require for holding its stock. It reflects the investor's perception of the risk associated with firm's future cash flows. The higher

\footnotetext{
${ }^{5}$ The opponents claim that CSR activities are in contradiction with the core functions of the controversial firms and therefore it is useless to talk about social responsible initiatives by an "irresponsible" corporation or industry. For instance, the World Health Organization (WHO) considers that CSR of the tobacco industry has an inherent contradiction because the core business of this industry is in conflict with the goals of public health policies with respect to tobacco control (WHO, 2003). In financial markets, some socially responsible investors choose to completely avoid firms in controversial industries including sin stocks such as those in tobacco, alcohol, gambling and military sectors.

For the proponents, firms in controversial businesses can engage in CSR activities and bring an important social contribution to the whole society and or to the environment. They can do so because its their legitimate right (Cai et al., 2012) and because such contribution may exceed that of firms from more mainstream areas (Lindorf et al., 2012). By minimising the harm that would be caused if their industry was unregulated or banned, these companies can make a real contribution to address some social problems.
} 
(lower) the perceived risk is, the higher (lower) the required risk premium and therefore the higher (lower) the cost of equity capital will be.

If CSR involvement reduces firm's risk, then one can directly link CSR to the cost of equity capital: the higher (lower) the CSR activities are, the lower (higher) the cost of equity will be. The key assumption underlying our expectation is that CSR mitigates firm's risk. Bellow, we provide three arguments in support to this assumption.

First, there are many reasons why a firm engages in CSR activities including risk management (Husted, 2005). Social responsibility enables firms to reduce the probability that they will face social and/or environmental crisis implying higher cash outflows. These cash outflows might be costly government imposed fines, clean-up costs in the case of environmental accidents or compensation related to problems associated with poor working conditions. Therefore, by avoiding future negative cash flows, CSR commitment will reduce firm's exposure to risk (Godfrey, 2005; El Ghoul et al., 2011) and consequently will decrease firm's cost of equity capital. Some empirical evidence for this theoretical argument exists. For instance, Feldman et al. (1997) find that investors perceive firms with higher environmental performance as less risky while Karpoff et al. (2005) results show that the size of stock price reaction to environmental violations is related to the regulatory and legal penalties.

Second, due to information asymmetry between stakeholders and the company management, gathering reliable information and verifying whether management activities are aligned with the interest of stakeholders become expensive. CSR may signal the quality of management to investors (Akpinar et al., 2008), and as such it decreases the monitoring and auditing costs. Consequently, high (low) CSR may decrease (increase) the required risk premium for holding the company's stock. Empirically, Hong and Kacperczyk (2009) find that sin stocks, i.e., companies involved in producing alcohol, tobacco, and gaming, receive less coverage from financial analysts and have higher expected returns than do stocks of otherwise comparable characteristics. Ioannou and Serafeim (2015) show that socially responsible firms receive more favourable recommendations from financial analysts.

Third, while finance theory suggests that investors should be perfectly diversified, various studies show they are not. Consequently, the investor base differs across stocks. Merton (1987) examines this situation using a theoretical model where investors invest only in stocks they are informed about. As a result, stocks of firms with smaller shareholder base and thus lower risk-sharing opportunities should yield higher expected returns. A similar model is developed by Heinkel et al., (2001) and predicts that investors demand a higher expected return as a compensation for holding more shares of polluting firms than they would hold in a market free of boycotts from so-called green investors. Hong and Kacperczyk (2009) provide empirical evidence that socially controversial firms, which are disliked by an important set of social norm-constrained investors, have smaller shareholder base. This translates in a limited risk sharing opportunities and therefore to a cheap stocks prices.

Overall, under the risk mitigation view we assume a lower cost of equity capital for firms with high CSR activities than for firms with low CSR activities because of a lower perceived risk, improved information transparency and due to a larger investor base. Thus, our first hypothesis is:

Hypothesis 1: CSR activities negatively affect the firm' cost of equity capital in controversial industry sectors. 
The description of the business activities as "controversial" should not hide the important heterogeneity that exists within the controversial industry sectors. Some industries are described as "controversial" based on social norms, the so-called "sinful industries", e.g., alcohol, tobacco, gambling, and adult entertainment (Lindgreen et al., 2012). Other controversial industries are described as such because of the externalities (i.e., environmental, social, governance or ethical issues) generated by the nature of their activities, e.g., defense/weapons, nuclear, oil, cement and biotech (Lindgreen et al., 2012; Cai et al., 2012).

In the same vein, the theoretical and empirical literature highlights the important role of the industry membership when studying the impact of CSR initiatives on firm's characteristics and attributes (Hendry, 2006; O'Connor and Shumate, 2010; Beschorner et al., 2013). Firms in the same industry share many stakeholders and are subject to the same regulatory constraints since policy-makers design regulations for specific industries (O'Connor and Shumate, 2010). Therefore, the effect of CSR on ICC will vary across the different controversial industry sectors. Accordingly, our second hypothesis is:

Hypothesis 2: The effect of CSR activities on firm' cost of equity capital is different depending on the controversial industry sector.

\section{Data and Methodology}

\subsection{Data}

Our data sample comes from the merge of four databases: MSCI ESG STATS (KLD) for social data; Thomson Reuters I/B/E/S for analyst earnings forecasts; CRSP for information on stock prices, stock returns, trading volumes, and shares outstanding; and COMPUSTAT for financial and accounting data.

Following Dhaliwal et al. (2006) and El Ghoul et al. (2011), we compute the cost of equity in each year using positive 1 and 2 years earnings forecasts as well as a positive long-term growth forecast. In addition, we require a positive book value per share, and that the firm belong to one of the Fama and French (1997) industries excluding financial and utility firms.

We follow Jo and $\mathrm{Na}$ (2012) and Cai et al. (2012) to assign firms to a controversial industry sector. This classification includes sinful industries, as in Hong and Kacperczyk (2009), such as alcohol, tobacco and gambling, as well as other controversial industries involved with emerging environmental, social, or ethical issues, such as defense-related weapons, nuclear, oil, cement and biotech. All SIC and NAICS codes for relevant industry sectors are reported in Appendix A. Our final sample is an unbalanced panel of 2,006 firm-year observations belonging to controversial industry sectors for the period from 1991 to 2012 as reported in Table 1.

\subsection{Methodology}

\subsubsection{Regression Model}

We follow prior studies (such as Hail and Leuz, 2006; Dhaliwal et al., 2006 and El Ghoul et al., 2011) in defining our regression models and in specifying control variables that affect the cost of equity capital. Our two baseline models directly link CSR score to the implied cost of equity capital (ICC) as follows: 


$$
\begin{aligned}
& I C C_{i, t}=\alpha_{0}+\alpha_{1} \operatorname{CSR}_{i, t}+\sum_{i} \sum_{t} C V_{i, t}+\varepsilon_{i, t} \\
& I C C_{i, t}=\alpha_{0}+\alpha_{1} C S R_{i, t}+\alpha_{2} C S R_{i, t} * \operatorname{Dum}_{i, t}+\sum_{i} \sum_{t} C V_{i, t}+\varepsilon_{i, t}
\end{aligned}
$$

Where:

$I C C_{i, t}$ : Cost of equity capital of firm $\mathrm{i}$ in year $\mathrm{t}$.

$C S R_{i, t}:$ : Corporate social responsibility score of firm $\mathrm{i}$ in year $\mathrm{t}$.

$\operatorname{Dum}_{i, t}$ : Dummy variable indicating the firm's belonging at time $\mathrm{t}$ to a controversial sector.

$C V_{i, t}$ : Vector of control variables of firm $\mathrm{i}$ in year $\mathrm{t}$.

All these variables are defined below.

Equation (2) enables us to capture the differential effect of CSR on ICC when the firm belongs to a specific sector of the controversial industries by adding an interaction term between CSR and the dummy variable $\left(\right.$ Dum $\left._{i, t}\right)$ representing this belonging.

\subsubsection{Measures of implied cost of equity capital}

For our dependant variable, we estimate the ex-ante cost of equity implied in current stock prices and analyst forecasts. According to this approach, the cost of equity is computed as the discount rate (or the internal rate of return) that equates the current stock price to the present value of all expected future cash flows. Several studies have used the implied cost of capital (ICC) approach along with forecasted earnings to estimate the cost of equity at the firm-level (e.g., Claus and Thomas, 2001; Easton, 2004; Ohlson and Juettner-Nauroth, 2005; Hail and Leuz, 2006; Lee, Ng, and Swaminathan, 2009). The ICC approach using forecasted earnings is appealing because it provides an ex ante cost of equity measure, as opposed to the measure provided by traditional asset pricing models which is based on ex post (realized) returns.

In the literature, various models are suggested to estimate the implied cost of equity. However, there is no consensus as to the best model(s) so that different papers use different models. In this paper, we follow Hail and Leuz (2006) and El Ghoul et al. (2011) and compute different models. We use five models, namely: the Claus and Thomas model (2001); the Lee, Ng, and Swaminathan model (2009); the Ohlson and Juettner model (2005); the MPEG ratio model of Easton (2004) and the PEG ratio model of Easton (2004). A detailed description of these models and their implementation is reported in Appendix B.

For each firm-year observation we compute the implied cost of equity using current stock price, book value per share, one-year-ahead and two-year-ahead mean earnings per share forecasts, payout ratio, five-year annualized mean (median) growth rate (an estimate for short-term growth), and an estimate for long-term growth rate.

Using the five ICC models, we obtain five different values for each firm-year observation. We follow Dhaliwal et al. (2006) and El Ghoul et al. (2011) and compute the average of the five models as our dependant variable and by doing so avoid any spurious results of one specific model.

\subsubsection{Measures of corporate social responsibility}

The CSR measures that we use in this study are constructed based on the MSCI ESG STATS (henceforth KLD) database. KLD database assesses firms by assigning binary scores (1 or zero) to seven qualitative screens (both strength and concern scores) and six exclusionary screens (with only concern scores). The qualitative screens (or dimensions) are community, diversity, employee relations, environment, product, human Rights, and corporate governance. The exclusionary screens are alcohol, gambling, firearms, military, nuclear power, and tobacco. 
For the purposes of this study and given the lack of consensus in the literature on how to weight the different KLD dimensions to produce reliable CSR measures, we follow some previous studies (e.g., Oikonomou et al., 2012; Bouslah et al., 2013) and use averages to compute our CSR variable. In addition, we exclude exclusionary screens following previous studies, (e.g., Oikonomou et al., 2012), and because it is more appropriate for our study in which controversies captured by these screens are embedded in the controversial industry classification used.

For each one out of the seven KLD dimensions, two averages are measured, respectively, for strengths and concerns (AVE_STR and AVE_CON):

$$
A V E_{-} S T R=\left[\frac{1}{N_{S T R}} \sum_{i=1}^{I} \text { Strength }_{i}\right] ; A V E_{-} C O N=\left[\frac{1}{N_{C O N}} \sum_{j=1}^{J} \text { Concern }_{j}\right]
$$

Where $N_{\text {STR }}$ and $N_{C O N}$ are the total maximum number of strengths and concerns within a given KLD dimension for each year. These individual measures enable us to compute an aggregate CSR score that we use for our analysis (CSR_index). It represents the difference between the sum of all the strengths' averages and the sum of all the concerns' averages.

\subsubsection{Control variables}

Following previous studies (e.g. Hail and Leuz, 2006; Dhaliwal et al., 2006, and El Ghoul et al., 2011) we control for firm-specific characteristics, industry factors, and economic or market-wide factors that affect the cost of equity capital. Specifically, these variables (their expected signs) are: beta (BETA) $(+)$, estimated using the market model; size (SIZE) (-), measured as the natural logarithm of total assets; the book-to-market ratio (BTM) $(+)$; leverage $(\mathrm{LEV})(+)$, computed as the ratio of total debt to the market value of equity; forecasted dispersion (DISP) $(+)$, measured as the coefficient of variation of 1-year-ahead earnings forecasts, and the consensus long-term growth forecast (LTG) (+). In addition, we control for year and industry effects using Fama-French (1997) 48 industry groups.

\subsection{Data summary}

Panel A in Table 1 summarizes the composition of our sample. There are 2,006 firm-year observations belonging to eight controversial industry sectors (alcohol, tobacco, gambling, military, firearms, cement oil and biotech) and covering the period from 1991 to 2012. Respectively, oil and biotech represent 42.87 and $40.43 \%$ of our sample.

Panel B, C and D in Table 1 report summary statistics for the implied cost of equity capital, CSR score and control variables of interest for our models. The mean of the ICC for the whole sample in panel B is $8.36 \%$. When we split this sample according to social responsibility commitment, we get an ICC of $8.15 \%$ for firms with high CSR scores (panel C) lower than $8.55 \%$ for firms with low CSR scores (panel D). This difference supports our first hypothesis but we need multivariate analysis since ICC depends on other variables.

$<<$ Please insert Table 1 about here $>>$

\section{Empirical results}

\subsection{Descriptive results}

Table 2 provides means and mean difference tests of our key variables (ICC and CSR). The CSR index panel reports means and mean differences of CSR score for firms in each controversial sector compared to CSR score of the remaining firms in the sample (i.e., firms in other controversial 
sectors). While the mean CSR score is -0.0385 for all controversial industries, there is certain heterogeneity in CSR among controversial industry sectors. Tobacco and biotech (alcohol, military, firearms, and oil) industries have significantly higher (lower) CSR scores than the remaining sample. Gambling and cement industries do not present any significant differences in CSR score than their sample counterpart.

In the ICC panel, we report means and mean differences for high and low CSR firms in all controversial sectors and in each controversial sector individually. For the whole controversial sample, the ICC of firms with high CSR is significantly lower, at 1\% level, than that of firms with lower CSR. For the individual subsamples of controversial industries, tobacco, cement and biotech show significant positive differences in the mean ICC. This implies that for the whole sample as well as for tobacco, cement and biotech industries, firms with high CSR pay lower cost of equity in accordance with our first hypothesis. The difference in results among controversial industry sectors gives support to our second hypothesis.

$<<$ Please insert Table 2 about here $>>$

Table 3 reports the Pearson correlation coefficients among our key variables for the 2,006 observations in controversial industry sectors. CSR score and ICC are negatively and significantly correlated at the $1 \%$ level. Additionally, all our explanatory variables exhibit significant correlation at the $1 \%$ level with the ICC and show the expected signs (positive for BETA, BTM, LEV, LTG and DISP and negative for SIZE). Finally, all correlations are not high and therefore multicollinearity cannot be an econometric issue for our regressions.

$$
<<\text { Please insert Table } 3 \text { about here }>>
$$

\subsection{Simultaneous equations system regressions}

Instead of using standard OLS regressions, we rely on simultaneous equation system estimation using Three Stage Least Squares (3SLS) regressions to examine the effect of CSR engagement on firm' cost of equity capital. The OLS regressions estimation of equation 1 and 2 assumes that CSR is exogenous. However, CSR may not be exogenous, and therefore OLS results may suffer from an endogeneity problem making them biased and inconsistent. For instance, firm's CSR commitment might not be independent from its cost of equity capital (El Ghoul et al., 2011) because of reverse causality. Simultaneous equation system estimation using 3SLS regressions enables us to correct for such potential endogeneity problem. Our simultaneous equation system is as follows:

$$
\begin{aligned}
& I C C_{i, t}=\alpha_{0}+\alpha_{1} \operatorname{CSR}_{i, t}+\alpha_{2} \operatorname{CSR}_{i, t} * \operatorname{Dum}_{i, t}+\sum_{i} \sum_{t} C V_{i, t}+\varepsilon_{i, t} \\
& \operatorname{CSR}_{i, t}=\beta_{0}+\beta_{1} I C C_{i, t}+\sum_{i} \sum_{t} C V_{i, t}+\varepsilon_{i, t}
\end{aligned}
$$

In the first (or ICC) equation, we use our basic model (equation 1 or 2) where we regress ICC on CSR score and the explanatory variables: beta (BETA); size (SIZE); the book-to-market ratio (BTM); leverage (LEV); forecast dispersion (DISP) and the consensus long-term growth forecast (LTG). In the second (or CSR) equation, we regress CSR score on ICC and known determinants of CSR engagement suggested by previous studies (e.g., Jo and Na, 2012): size (SIZE); leverage (LEV) and profitability (ROA). In addition, we control for year and industry effects using FamaFrench (1997) 48 industry groups.

Table 4 reports the results of 3SLS regressions for our sample of controversial industry sectors. The coefficient of CSR variable $\left(\alpha_{1}\right)$ in the system of equation 1 is negative and significant at $1 \%$ level. The estimates of the same CSR coefficient $\left(\alpha_{1}\right)$ in the other systems of equation (2 to 9 
which integrate different dummies for controversial sectors belonging) show a same negative and significant result at the $1 \%$ level. Together, these results support our first hypothesis

In the systems of equation 2 to 9, an interaction term between CSR and a dummy variable representing an individual controversial industry sector (alcohol, tobacco, gambling, military, firearms, cement, oil and biotech) is added. This interaction term $\left(\alpha_{2}\right)$ captures the incremental effect of CSR on ICC when the firm belongs to a particular individual controversial sector.

The obtained estimates of the interaction terms reveal important differences among the controversial sectors. The negative and significant $\alpha_{2}$ in the system of equation 2 and 3 shows that the effect of CSR on ICC is more pronounced in the alcohol and tobacco sectors. By contrast, the positive and significant (at $10 \%$ level) $\alpha_{2}$ in the system of equation 8 indicates that the effect of CSR on ICC is less pronounced in the oil sector. The remaining results of the interaction terms for the other sectors are insignificant. These differences in the interaction terms reveal that the impact of CSR activities on firm' cost of equity capital depends on the controversial industry sector which gives support to our second hypothesis.

In addition, while the coefficient $\alpha_{1}$ captures the effect of CSR on ICC for the whole sample, the sum of $\alpha_{1}$ and $\alpha_{2}$ captures the same impact for a specific industry sector. All the findings for the systems of equation 2 to 9 give a negative sum $\left(\alpha_{1}+\alpha_{2}\right)$ and therefore support our first hypothesis for each individual controversial industry sector.

Overall, the simultaneous equations system regressions show three main results. First, the effect of CSR on ICC (as measured by $\alpha_{1}$ ) is significant and negative in all controversial industry sectors. Second, the same negative impact is obtained in each controversial industry sector as captured by the sum of the coefficients $\alpha_{1}$ and $\alpha_{2}$. Third, this effect is heterogeneous among these sectors. It is more (less) pronounced when the firm belongs to the alcohol and tobacco (oil) industry sectors. ${ }^{6}$

$<<$ Please insert Table 4 about here $>>$

Our finding that CSR commitment reduces ICC of firms in controversial industry sectors is consistent with the literature (El Ghoul et al., 2011; Jo and Na, 2012; Bouslah et al., 2013). However, the reader might wonder whether this finding implies that CSR helps firm access to financing. To explore this implication, we examine the relation between CSR on Kaplan and Zingales index (1997). We find, that CSR decreases financial constraints, and therefore improves firm's access to external financing in general. This result is consistent with our finding. ${ }^{7}$

Another implication possibility is that our finding might translates into higher firm value, cashflows and profitability. We explore this possibility by examining the effect of CSR on these three variables. We find that CSR is not significantly related to firm value and to accounting profitability in our sample period. However, we find evidence that CSR positively affects firm's cash flows. ${ }^{8}$

\footnotetext{
${ }^{6}$ Our results are qualitatively similar when using lagged values of CSR scores.

${ }^{7}$ Thanks to an anonymous referee who raise the potential effect of CSR on access to financing in controversial sectors. In line with our evidence that CSR reduces the ICC, we also find, that CSR decreases financial constraints, as measured by Kaplan and Zingales index (1997), and therefore improves firm's access to external financing in general. The results are not reported and available upon request.

${ }^{8}$ As pointed out by an anonymous referee, our findings of CSR reduction effect on the cost of equity do not necessarily implies an increase or decrease of future cash-flows, accounting profits and ultimately firm value. We do recognise
} 
Additionally, while our finding of the negative impact of CSR on ICC supports prior literature, one would wonder whether is it different from that of firms in non-controversial sectors. We test and find that the link between CSR and ICC for firms in controversial sectors is more pronounced than that for firms in non-controversial industries. ${ }^{9}$

\section{Robustness checks}

In this section, we conduct additional tests in order to examine the robustness of our results in Table 4. Respectively we use alternative measures of our key variables: ICC and CSR and we rerun instrumental variable regressions analysis.

\subsection{Alternative measures of the implied cost of equity capital}

As mentioned earlier, we follow Hail and Leuz (2006) and El Ghoul et al. (2011) in computing ICC using different models: the Claus and Thomas model (2001); the Lee, Ng, and Swaminathan model (2009); the Ohlson and Juettner model (2005); the MPEG ratio model of Easton (2004) and the PEG ratio model of Easton (2004). Then, we compute the average of these five models and use it in our analysis. For robustness check, we re-compute two other averages using four models: the first three models and, respectively, the PEG ratio model of Easton (2004) and the MPEG ratio model of Easton (2004). We re-run our 3SLS regressions and the results are reported in Table 9 (average ICC using PEG ratio model of Easton) and Table 10 (average ICC using MPEG ratio model of Easton). Only the first equation of the estimated system of equations is reported.

The results in Tables 5 are qualitatively similar to those reported in Table 4. Consequently, our earlier results in Table 4 still hold.

$$
<<\text { Please insert Table } 5 \text { about here }>>
$$

\subsection{Alternative measures of CSR score}

Since there is no consensus among academics on how to measure CSR score using KLD data, different methods have been used in the literature. To assess the robustness of our results in Table 4, we construct an alternative CSR score computed as the difference between total KLD strengths

that doing socially responsible activities and engagement are costly (i.e., it consumes money and generates expenses), and the academic literature is not clear about whether this helps to generate more revenue by attracting more socially and environmentally consumers. Such implications are more complex and beyond the scope of this study. Nonetheless, we also explore the relationships between CSR and firm value, as measured by Tobin's Q, accounting profit (ROA) and cash-flows in our sample.

First, we follow Cai et al. (2012) and directly link firm value to CSR commitment. The results show that CSR is not significantly related to firm value when examining the whole sample period (1991-2012). However, when we replicate the work of Cai et al. (2012) whose sample period ends in 2009, we find a qualitatively similar positive and significant effect of CSR on firm value. Our findings imply that the relation between CSR and firm value could be heavily influenced by the 2007-2008 financial crisis. Second, we regress accounting profit (ROA) on CSR and a set of control variables. The results show that CSR does not impact firm return on assets. Third, we regress firm cash-flows on CSR and a set of control variables. We find that CSR commitment positively affects firm's cash-flows.

All the results are not reported and available upon request.

${ }^{9}$ Thanks to an anonymous referee who point out to the potential difference between the effect of CSR on ICC for firms in controversial sectors and those in non-controversial sectors. We also run our main regression for the sample of firms in non-controversial industries. The untabulated results show that the negative impact of CSR on ICC is more pronounced for firms in controversial sectors. An increase in CSR score by one standard deviation decreases the firm's cost of equity capital by $-0.60 \%$ for firms in non-controversial industries and by $-2.13 \%$ for firms in controversial industry sectors. 
and total KLD concerns. We re-run our 3SLS regressions and the results are presented in Table 6. Only the first equation of the estimated system of equations is reported.

In all systems of equations (1-9), the coefficient of CSR score $\alpha_{1}$ is negative and significant at the $1 \%$ level which supports our earlier results in Table 4 . For the incremental effect of CSR on ICC, captured by the interaction term $\left(\alpha_{2}\right)$, when the firm belongs to an individual controversial sector, the results are similar to those in Table 4. The coefficient $\alpha_{2}$ is negative and significant respectively, at the 5\% and the $10 \%$ level, for alcohol and tobacco. However, the coefficient $\alpha_{2}$ for firms in oil sector becomes insignificant.

In summary, the three main results hold and confirm our estimates in Table 4. First, CSR score negatively and significantly affects ICC in the sample of firms in controversial industries $\left(\alpha_{1}\right)$. Second, CSR score negatively affects ICC in all the evaluated controversial industry sectors $\left(\alpha_{1}+\alpha_{2}\right)$ individually. Third, the negative effect of CSR on ICC is more pronounced when the firm belongs to the alcohol and tobacco sectors.

$$
<<\text { Please insert Table } 6 \text { about here }>>
$$

\subsection{Instrumental variable regressions}

As a robustness check of our simultaneous equations system regressions results, we use instrumental variable regressions. We instrument CSR variable and re-run two-stage least squares estimations for all models in Table 4. We follow past studies (e.g., Goss and Roberts, 2011) and use average industry CSR score, 3-years lagged firm' CSR scores and a dummy variable reflecting whether the state in which the firm operates voted for the Democratic Candidate in presidential elections.

The results of the two-stage least squares regressions are reported in Table 7. Except for the incremental effect of CSR on ICC for oil sector which becomes insignificant, the obtained findings are qualitatively similar to those reported in Table 4. Consequently, our main results in Table 4 still hold.

$$
<<\text { Please insert Table } 7 \text { about here }>>
$$

\section{Conclusion}

This paper examines whether firm's CSR commitment affects its cost of equity capital when the firm belongs to controversial industry sectors. Based on three theoretical arguments, namely, firm perceived risk, asymmetric information and investor base, it hypothesizes that CSR activities, through their risk mitigation effect, are expected to reduce required risk premium of holding firm' stock and therefore its cost of equity. For our tests, we use a U.S. sample of 2,006 firm-year observations belonging to controversial industry sectors covering the period from 1991 to 2012 . We find two main results. First, CSR engagement significantly reduces ICC in all controversial industry sectors, as a group, as well as in each one of these sectors individually. Second, this effect is heterogeneous among these sectors. It is more pronounced when the firm belongs to the alcohol and tobacco industry sectors.

Our findings have two important practical implications. First, they should increase managers' confidence and incentives, in controversial industry sectors, to pursue CSR activities. Firms in these sectors can undertake socially and environmentally worthy actions while benefiting from a cheaper equity financing costs. Moreover, these costs can be more attractive for some controversial sectors such as alcohol and tobacco. Second, policymakers can encourage managers to undertake CSR initiatives in controversial industry sectors through tax incentives (e.g., reduce taxes for CSR related investment projects). 
Although we conducted a battery of robustness tests in order to ensure the validity of our results, our work could have some limitations that are left for future research. First, by relying on an aggregate measure of CSR, we are probably missing important information that can help explain variations in the ICC. Therefore, future research could examine the CSR-ICC link by separating the seven different KLD dimensions as well as strengths and concerns of these dimensions.

Another limitation is the classification of industries as controversial. Given the scarcity of studies in this field, we adopted the classification of Jo and $\mathrm{Na}$ (2012). However, this classification could be limited since it does not include some other known controversial sectors such as mining, chemicals and transportation. Moreover, this classification treats all controversial issues equally. In other words, it is assumed that investors consider a similar impact of CSR on ICC in controversial sectors. However, investors could perceive controversial sectors differently, e.g., abortion and gambling may not be perceived equally by investors. Future research can explore other more extended and appropriate classifications that reflect the investor's perceptions. 


\section{References}

Akpinar, A., Jiang, Y., Gomes-Mejia, L.R., Berrone, P., Walls, J.L., 2008. Strategic Use of CSR as A Signal for Good Management. IE Business School Working Paper, WP08-25.

Barnea, A., Rubin, A., 2010. Corporate social responsibility as a conflict between shareholders. Journal of Business Ethics 97, 71-86.

Barraclough, S., Morrow, M., 2008. A grim contradiction: The practice and consequences of corporate social responsibility by British American Tobacco in Malaysia. Social Science \& Medicine 66, 1784-1796.

Beschorner, T., Hajduk, T., Simeonov, S., 2013. Sector-specific corporate responsibility in Europe: introduction, in Beschorner, T., Hajduk, T. and Simeonov, S. (Eds), Corporate Responsibility in Europe, Verlag Bertelsmann Stiftung, Gütersloh, 23-39.

Bouslah, K., Kryzanowski, L., M'zali, B., 2013. The impact of the dimensions of social performance on firm risk. Journal of Banking \& Finance 37(4), 1258-1273.

Cahan, S. F., Chen, C., Chen, L., Nguyen, N. H., 2015. Corporate social responsibility and media coverage. Journal of Banking \& Finance 59, 409-422.

Cai, Y., Jo, H., Pan, C., 2012. Doing Well While Doing Bad? CSR in Controversial Industry Sectors. Journal of Business Ethics 108, 467-480.

Claus, J., Thomas, J., 2001. Equity premia as low as three percent? Evidence from analysts' earnings forecasts for domestic and international stock markets. Journal of Finance 56, 1629-1666.

Dhaliwal, D., Eheitzman, S., Li, O.Z., 2006. Taxes, leverage, and the cost of equity capital. Journal of Accounting Research 44, 691-723.

Du, S., Vieira, E.T., 2012. Striving for Legitimacy Through Corporate Social Responsibility: Insights from Oil Companies. Journal of Business Ethics 110 (4), 413-427.

Easton, P.D., 2004. PE ratios, PEG ratios, and estimating the implied expected rate of return on equity capital. The Accounting Review 79, 73-95.

El Ghoul, S., Guedhami, O., Kwok, C., Mishra, D., 2011. Does corporate social responsibility affect the cost of capital? Journal of Banking \& Finance 35(9), 2388-2406.

Fama, E.F., French, K.R., 1997. Industry cost of equity. Journal of Financial Economics 43, 153193.

Feldman, J., Soyka, P., Ameer, P., 1997. Does improving a firm's environmental management system and environmental performance result in a higher stock price? Journal of Investing 6, 8797.

Friedman, M., 1970. The social responsibility of business is to increase its profits. The New York Times Magazine 13, 32-33.

Frynas, J.G., 2009. Corporate social responsibility in the oil and gas sector. The Journal of World Energy Law \& Business 2(3), 178-195.

Godfrey, P. C., 2005. The relationship between corporate philanthropy and shareholder wealth: A risk management perspective. Academy of Management Review 30, 777-798. 
Goss, A., Roberts, G. S., 2011. The impact of corporate social responsibility on the cost of bank loans. Journal \& Banking and Finance 35, 1794-1810.

Grougiou, V., Dedoulis, E., Leventis, S., 2016. Corporate Social Responsibility Reporting and Organizational Stigma: The Case of "Sin” Industries. Journal of Business Research 69, 905-914.

Hail, L., Leuz, C., 2006. International differences in cost of equity capital: do legal institutions and securities regulations matter? Journal of Accounting Research 44, 485-531.

Hendry, J.R., 2006. Taking aim at business: what factors lead environmental nongovernmental organizations to target particular firms?, Business \& Society, 45-1, 47-86.

Heinkel, R., Kraus, A., Zechner, J., 2001. The effect of green investment on corporate behaviour. Journal of Financial and Quantitative Analysis 36, 431-449.

Jo, H., Na, H., 2012. Does CSR Reduce Firm Risk? Evidence from Controversial Industry Sectors. Journal of Business Ethics 110:441-456

Hong, H., Kacperczyk, M., 2009. The price of sin: The effects of social norms on markets. Journal of Financial Economics 93, 15-36.

Husted, B.W., 2005. Risk Management, real options, and corporate social responsibility. Journal of Business Ethics 60, 175-183.

Ioannou, I., Serafeim, G., 2015. The Impact of Corporate Social Responsibility on Investment recommendations: Analysts' perceptions and shifting institutional logics. Strategic Management Journal,36, 1053-1081.

Karpoff, J.M., Lott J.R., Wehrly, E.W., 2005. The Reputational Penalties for Environmental Violations: Empirical Evidence. Journal of Law and Economics 48, 653-675.

Kotchen, M., Moon, J. J., 2012. Corporate Social Responsibility for Irresponsibility. The B.E. Journal of Economic Analysis \& Policy, 12(1), Article 55, doi: 10.1515/1935-1682.3308.

Lee, C., Ng, D., Swaminathan, B., 2009. Testing international asset pricing models using implied costs of capital. Journal of Financial and Quantitative Analysis 44, 307-335.

Lindorff, M., Jonson, E.P., McGuire, L., 2012. Strategic Corporate Social Responsibility in Controversial Industry Sectors: The Social Value of Harm Minimisation. Journal of Business Ethics 110, 457-467.

Lindgreen, A., Maon, F., Reast, J., Yani-De-Soriano, M., 2012. Guest Editorial: Corporate Social Responsibility in Controversial Industry Sectors, Journal of Business Ethics, 110, 393-395. DOI 10.1007/s10551-012-1488-y.

Margolis, J. D., Elfenbein, H. A., Walsh, J. P., 2007. Does it pay to be good? A meta-analysis and redirection of research on the relationship between corporate social and financial performance. Working paper, Harvard business school, Cambridge.

Merton, R.C., 1987. A simple model of capital market equilibrium with incomplete information. Journal of Finance 42, 483-510.

O'Connor, A. and Shumate, M., 2010. An economic industry and institutional level of analysis of corporate social responsibility communication, Management Communication Quarterly, 24-4, 529-551. 
Ohlson, J., Juettner-Nauroth, B., 2005. Expected EPS and EPS growth as determinants of value. Review of Accounting Studies 10, 349-365.

Oikonomou, I., Brooks, C., Pavelin, S., 2012. The impact of corporate social performance on financial risk and utility: a longitudinal analysis. Financial Management 41, 483-515.

Palazzo, G., Richter, U., 2005. CSR business as usual? The case of the tobacco industry. Journal of Business Ethics 61(4), 387-401.

Porter, M. E., Kramer, M. K., 2011. Creating shared value: How to reinvent capitalism and unleash a wave of innovation and growth. Harvard Business Review 89(1-2), 62-77.

Renneboog, L., Ter Horst, J., Zhang, C., 2008. Socially responsible investments: Institutional aspects, performance, and investor behavior. Journal of Banking \& Finance 32, 1723-1742.

Rodrigo, P., Duran, I. and Arenas, D., (2016). Does it really pay to be good, everywhere? A first step to understand the corporate social and financial performance link in Latin American controversial industries, Business Ethics A European Review, 25, 286-309. DOI: 10.1111/beer.12119.

Sharfman, M.P., Fernando, C.S., 2008. Environmental risk management and the cost of capital. Strategic Management Journal 29, 569-592.

Strahilevitz, M., 2003. The effects of prior impressions of a firm's ethics on the success of a causerelated marketing campaign: Do the good look better while the bad look worse? Journal of Nonprofit and Public Sector Marketing 11, 77-92.

US SIF Foundation, 2006. Biennial Report on US Sustainable, Responsible and Impact Investing Trends. http://www.ussif.org/files/SIF Trends 16 Executive Summary(1).pdf.

World Health Organization, 2003. Tobacco industry and corporate responsibility....an inherent contradiction. http://www.who.int/tobacco.

Yoon, Y., Gurhan-Canli, Z., Schwarz, N., 2006. The effect of corporate social responsibility (CSR) activities on companies with bad reputations. Journal of Consumer Psychology 16(4), 377-390. 
Table 1: Sample distribution and Summary statistics

\begin{tabular}{lcc}
\hline \multicolumn{3}{l}{ Panel A: Sample distribution } \\
\hline Flcohol & Firm-year observations & Percent \\
\hline Tobacco & 59 & 2.94 \\
Gambling & 132 & 6.58 \\
Military & 89 & 4.44 \\
Firearms & 32 & 1.60 \\
Nuclear energy & 19 & 0.95 \\
Cement & 0 & 0.00 \\
Oil & 4 & 0.20 \\
Biotech & 860 & 42.87 \\
T0otal & 811 & 40.43 \\
\hline
\end{tabular}

\begin{tabular}{lccccc}
\hline \multicolumn{6}{l}{ Panel B: All controversial industry sectors sample } \\
\hline \multicolumn{7}{c}{ Mean } & Median & Std dev & Minimum & Maximum \\
\hline ICC & 0.0836 & 0.0792 & 0.0330 & 0.0042 & 0.2758 \\
CSR index & -0.0385 & -0.0429 & 0.1050 & -0.4643 & 0.5688 \\
BETA & 1.0113 & 0.9458 & 0.4495 & 0.1312 & 2.6792 \\
BTM & 0.3913 & 0.3335 & 0.3043 & 0 & 4.6518 \\
SIZE & 8.6794 & 8.4782 & 1.6265 & 2.9857 & 13.1308 \\
LEV & 0.2484 & 0.1529 & 0.2951 & 0 & 1.3432 \\
LTG & 0.1575 & 0.13 & 0.1107 & 0 & 1.3665 \\
DISP & 0.0650 & 0.0401 & 0.0876 & 0 & 1.4390 \\
ROA & 0.1403 & 0.1311 & 0.1250 & -0.5981 & 0.4885 \\
\hline
\end{tabular}

\begin{tabular}{lcccccc}
\hline \multicolumn{7}{l}{ Panel C: Controversial industry sectors sample with high CSR } \\
\hline \multicolumn{1}{l}{$\mathrm{N}$} & Mean & Median & Std dev & Minimum & Maximum \\
\hline ICC & 948 & 0.0815 & 0.0764 & 0.0310 & 0.0042 & 0.2616 \\
CSR index & 948 & 0.0293 & 0 & 0.0952 & -0.1595 & 0.5687 \\
BETA & 948 & 1.0229 & 0.9658 & 0.4563 & 0.1312 & 2.6001 \\
BTM & 948 & 0.3812 & 0.3242 & 0.2848 & 0 & 2.7531 \\
SIZE & 948 & 8.5562 & 8.2356 & 1.6440 & 2.9857 & 12.9023 \\
LEV & 948 & 0.234 & 0.1501 & 0.2828 & 0 & 1.3432 \\
LTG & 948 & 0.1619 & 0.14 & 0.1129 & 0 & 1.3665 \\
DISP & 948 & 0.0672 & 0.0403 & 0.1046 & 0 & 1.439 \\
ROA & 948 & 0.1420 & 0.1361 & 0.1292 & -0.5981 & 0.4885 \\
\hline
\end{tabular}

\begin{tabular}{cccccc}
\hline \multicolumn{6}{c}{ Panel D: Controversial industry sectors sample with low CSR } \\
\hline $\mathrm{N}$ & Mean & Median & Std dev & Minimum & Maximum \\
\hline 1058 & 0.0855 & 0.0809 & 0.0345 & 0.0042 & 0.2758 \\
1058 & -0.0993 & -0.0870 & 0.0706 & -0.4643 & 0.2051 \\
1058 & 1.0009 & 0.9377 & 0.4434 & 0.1312 & 2.6792 \\
1058 & 0.4003 & 0.3390 & 0.3207 & 0 & 4.6518 \\
1058 & 8.7898 & 8.6406 & 1.6033 & 3.7382 & 13.1308 \\
1058 & 0.2614 & 0.1583 & 0.3053 & 0 & 1.3432 \\
1058 & 0.1534 & 0.13 & 0.1086 & 0 & 1 \\
1058 & 0.0630 & 0.0398 & 0.0689 & 0 & 0.6991 \\
1058 & 0.1388 & 0.1272 & 0.1211 & -0.5742 & 0.4885 \\
\hline
\end{tabular}

This table presents the sample distribution by controversial industry sector (panel A) and displays descriptive statistics for the sample over the period from 1991 to 2012 (panel B, C and D). Mean, median, standard deviation, minimum and maximum values are reported. Panel B reports statistics for firms in all controversial industry sectors. Panel C and D report statistics for firms in controversial industry sectors segmented by CSR score (high versus low). ICC is the average implied cost of equity obtained from five models: Appendix B provides details on the implementation of the five models. All SIC and NAICS codes used to assign firms to Controversial industry sectors are reported in Appendix A. The segmentation of CSR index (high versus low) is based on the industry median for each given year (above versus below). BETA is beta estimated using the market model; SIZE: firm' size measured as the natural logarithm of total assets; BTM: Firm' bookto-market ratio; LEV is the leverage and computed as the ratio of total debt to the market value of equity; DISP is the forecast dispersion measured as the coefficient of variation of 1-year-ahead earnings forecasts; and LTG is the consensus long-term growth forecast. All the continuous variables are winsorized at the first and the $99^{\text {th }}$ percentile. 
Table 2: Mean comparison of the key variables (ICC and CSR)

\begin{tabular}{|c|c|c|c|c|c|c|}
\hline \multirow{2}{*}{$\begin{array}{l}\text { Controversial } \\
\text { Industry }\end{array}$} & \multicolumn{3}{|c|}{ CSR_index } & \multicolumn{3}{|c|}{$\mathrm{ICC}$} \\
\hline & $\begin{array}{l}\text { Controversial } \\
\text { subsample(1) }\end{array}$ & $\begin{array}{c}\text { Without } \\
\text { subsample(2) }\end{array}$ & $\begin{array}{l}\text { Difference } \\
\text { (2)-(1) }\end{array}$ & $\begin{array}{l}\text { High CSR } \\
\text { (1) }\end{array}$ & $\begin{array}{c}\text { Low CSR } \\
\text { (2) }\end{array}$ & $\begin{array}{l}\text { Difference } \\
(2)-(1)\end{array}$ \\
\hline All controversial & -0.0385 & & & 0.08152 & 0.08551 & $0.00399 * * *$ \\
\hline Alcohol & -0.0817 & -0.0372 & $0.0445 * * *$ & 0.10399 & 0.0956 & -0.00839 \\
\hline Tobacco & 0.0040 & -0.0415 & $-0.0456 * * *$ & 0.06853 & 0.07368 & $0.00515^{* *}$ \\
\hline Gambling & -0.0456 & -0.0382 & 0.0073 & 0.08612 & 0.08837 & 0.00224 \\
\hline Military & -0.0836 & -0.0378 & $0.0458 * * *$ & 0.07293 & 0.07571 & 0.00279 \\
\hline Firearms & -0.0699 & -0.0382 & $0.0316^{*}$ & 0.11149 & 0.10305 & -0.00844 \\
\hline Cement & -0.10068 & -0.0384 & 0.0623 & 0.02519 & 0.10371 & $0.07852 * * *$ \\
\hline Oil & -0.06234 & -0.0207 & $0.0416 * * *$ & 0.08626 & 0.08888 & 0.00262 \\
\hline Biotech & -0.01351 & -0.0555 & $-0.0420 * * *$ & 0.0768 & 0.08241 & $0.00561 * * *$ \\
\hline
\end{tabular}

This table provides means and mean difference comparisons of our key variables (ICC and CSR). The ICC panel gives means and mean differences for high and low CSR firms in all controversial sectors and in each controversial sector. The CSR index panel reports means and mean differences of CSR score for firms in all controversial sectors and in each controversial sector compared to CSR score of the remaining firms in the sample. The definition of ICC is provided in Table $1 .{ }^{* * *},{ }^{* *},{ }^{*}$ indicate significance at the $1 \%, 5 \%$ and $10 \%$ levels, respectively.

\section{Table 3: Correlation matrix}

\begin{tabular}{|c|c|c|c|c|c|c|c|c|}
\hline Variables & (1) & (2) & (3) & (4) & (5) & (6) & (7) & $(8)$ \\
\hline ICC (1) & 1.00 & & & & & & & \\
\hline CSR index (2) & $-0.08 * * *$ & 1.00 & & & & & & \\
\hline BETA (3) & $0.20 * * *$ & $-0.05 * *$ & 1.00 & & & & & \\
\hline BTM (4) & $0.15 * * *$ & $-0.05 * *$ & $0.18 * * *$ & 1.00 & & & & \\
\hline SIZE (5) & $-0.15 * * *$ & $0.01 * *$ & $-0.30 * * *$ & $-0.28 * * *$ & 1.00 & & & \\
\hline LEV (6) & $0.13 * * *$ & $-0.07 * * *$ & $0.11 * * *$ & $0.51 * * *$ & $-0.28 * * *$ & 1.00 & & \\
\hline LTG (7) & $0.32 * * *$ & -0.03 & $0.29 * * *$ & $-0.16^{* * *}$ & $-0.21 * * *$ & $-0.15^{* * *}$ & 1.00 & \\
\hline DISP (8) & $0.17 * * *$ & $-0.05 * *$ & $0.24 * * *$ & $0.07 * * *$ & $-0.16 * * *$ & $0.09 * * *$ & $0.45 * * *$ & 1.00 \\
\hline
\end{tabular}

This table reports the Pearson correlation coefficients among our main variables for the 2006 observations of firms in controversial industry sectors from 1991 to 2012. See Table 1 for variable definitions. All the continuous variables are winsorized at the first and the $99^{\text {th }}$ percentile. ${ }^{* * *},{ }^{* *},{ }^{*}$ indicate significance at the $1 \%$, $5 \%$ and $10 \%$ levels, respectively. 
Table 4: Simultaneous equations system estimation results

\begin{tabular}{|c|c|c|c|c|c|c|c|c|}
\hline & & & \multicolumn{6}{|c|}{ Model with interaction in ICC equation between CSR and dummy variable } \\
\hline & \multicolumn{2}{|c|}{ System 1} & \multicolumn{2}{|c|}{ System 2} & \multicolumn{2}{|c|}{ System 3} & \multicolumn{2}{|c|}{ System 4} \\
\hline & ICC & CSR & ALC & CSR & TOB & CSR & GAM & CSR \\
\hline CSR & $\begin{array}{c}-0.179 * * * \\
(-5.628)\end{array}$ & . & $\begin{array}{c}-0.113 * * * \\
(-3.548)\end{array}$ & . & $\begin{array}{c}-0.177 * * * \\
(-5.534)\end{array}$ & . & $\begin{array}{c}-0.198 * * * \\
(-6.888)\end{array}$ & . \\
\hline CSR*Dummy & & & $\begin{array}{l}-0.067 * \\
(-1.781)\end{array}$ & & $\begin{array}{c}-0.079 * * \\
(-2.348)\end{array}$ & & $\begin{array}{c}0.040 \\
(0.889)\end{array}$ & \\
\hline BETA & $\begin{array}{c}0.001 \\
(0.696)\end{array}$ & & $\begin{array}{c}0.002 \\
(0.825)\end{array}$ & & $\begin{array}{c}0.001 \\
(0.630)\end{array}$ & & $\begin{array}{c}0.001 \\
(0.345)\end{array}$ & \\
\hline SIZE & $\begin{array}{c}-0.001 \\
(-0.919)\end{array}$ & $\begin{array}{l}-0.003 * \\
(-1.762)\end{array}$ & $\begin{array}{c}-0.000 \\
(-0.504)\end{array}$ & $\begin{array}{l}-0.003 * \\
(-1.681)\end{array}$ & $\begin{array}{c}-0.001 \\
(-1.147)\end{array}$ & $\begin{array}{c}-0.003 * * \\
(-1.987)\end{array}$ & $\begin{array}{c}-0.001 \\
(-1.024)\end{array}$ & $\begin{array}{l}-0.003 * \\
(-1.705)\end{array}$ \\
\hline BTM & $\begin{array}{c}0.011 * * * \\
(4.666)\end{array}$ & & $\begin{array}{c}0.013 * * * \\
(5.085)\end{array}$ & & $\begin{array}{c}0.011 * * * \\
(4.548)\end{array}$ & & $\begin{array}{c}0.011 * * * \\
(4.482)\end{array}$ & \\
\hline LEV & $\begin{array}{c}0.008 * * \\
(2.450)\end{array}$ & $\begin{array}{c}-0.010 \\
(-1.136)\end{array}$ & $\begin{array}{c}0.010^{* * *} \\
(3.402)\end{array}$ & $\begin{array}{c}-0.007 \\
(-0.737)\end{array}$ & $\begin{array}{c}0.007 * * \\
(2.426)\end{array}$ & $\begin{array}{c}-0.009 \\
(-0.933)\end{array}$ & $\begin{array}{c}0.008 * * \\
(2.557)\end{array}$ & $\begin{array}{c}-0.010 \\
(-1.138)\end{array}$ \\
\hline LTG & $\begin{array}{c}0.088 * * * \\
(10.937)\end{array}$ & & $\begin{array}{c}0.094 * * * \\
(12.554)\end{array}$ & & $\begin{array}{c}0.083 * * * \\
(10.487)\end{array}$ & & $\begin{array}{c}0.089 * * * \\
(11.322)\end{array}$ & \\
\hline DISP & $\begin{array}{c}-0.013 \\
(-1.629)\end{array}$ & & $\begin{array}{c}-0.013 \\
(-1.583)\end{array}$ & & $\begin{array}{c}-0.012 \\
(-1.540)\end{array}$ & & $\begin{array}{l}-0.014^{*} \\
(-1.794)\end{array}$ & \\
\hline ICC & & $\begin{array}{c}-0.803 * * * \\
(-4.091)\end{array}$ & & $\begin{array}{c}-0.636^{* * *} \\
(-3.263)\end{array}$ & & $\begin{array}{c}-0.973 * * * \\
(-4.934)\end{array}$ & & $\begin{array}{c}-0.747 * * * \\
(-3.806)\end{array}$ \\
\hline ROA & & $\begin{array}{c}-0.034 * * \\
(-2.267)\end{array}$ & & $\begin{array}{c}-0.027 \\
(-1.590)\end{array}$ & & $\begin{array}{c}-0.033 * * \\
(-2.204)\end{array}$ & & $\begin{array}{c}-0.033 * * \\
(-2.111)\end{array}$ \\
\hline Constant & $\begin{array}{c}0.052 * * * \\
(6.976)\end{array}$ & $\begin{array}{c}0.041 \\
(1.591)\end{array}$ & $\begin{array}{c}0.049 * * * \\
(7.137)\end{array}$ & $\begin{array}{c}0.023 \\
(0.875)\end{array}$ & $\begin{array}{c}0.054 * * * \\
(7.342)\end{array}$ & $\begin{array}{c}0.057 * * \\
(2.174)\end{array}$ & $\begin{array}{c}0.052 * * * \\
(7.186)\end{array}$ & $\begin{array}{c}0.037 \\
(1.410)\end{array}$ \\
\hline Industry FE & NO & YES & NO & YES & NO & YES & NO & YES \\
\hline Year FE & YES & YES & YES & YES & YES & YES & YES & YES \\
\hline Observations & 2,006 & 2,006 & 2,006 & 2,006 & 2,006 & 2,006 & 2,006 & 2,006 \\
\hline F-test & 17.19 & 16.44 & 20.40 & 16.93 & 19.66 & 16.52 & 18.19 & 16.11 \\
\hline P-value & 0.00 & 0.00 & 0.00 & 0.00 & 0.00 & 0.00 & 0.00 & 0.00 \\
\hline
\end{tabular}


Table 4: Simultaneous equations system estimation results (Continued)

\begin{tabular}{|c|c|c|c|c|c|c|c|c|c|c|}
\hline & \multicolumn{10}{|c|}{ Model with interaction in ICC equation between CSR and dummy variable } \\
\hline & \multicolumn{2}{|c|}{ System 5} & \multicolumn{2}{|c|}{ System 6} & \multicolumn{2}{|c|}{ System 7} & \multicolumn{2}{|c|}{ System 8} & \multicolumn{2}{|c|}{ System 9} \\
\hline & MIL & CSR & FIR & CSR & CEM & CSR & OIL & CSR & $\mathrm{BIO}$ & CSR \\
\hline$\overline{\mathrm{CSR}}$ & $\begin{array}{c}-0.187^{* * *} \\
(-5.515)\end{array}$ & . & $\begin{array}{c}-0.179 * * * \\
(-5.387)\end{array}$ & . & $\begin{array}{c}-0.187 * * * \\
(-5.798)\end{array}$ & . & $\begin{array}{c}-0.247 * * * \\
(-7.113)\end{array}$ & . & $\begin{array}{c}-0.161 * * * \\
(-6.635)\end{array}$ & . \\
\hline CSR*Dummy & $\begin{array}{c}-0.009 \\
(-0.218)\end{array}$ & & $\begin{array}{c}-0.048 \\
(-0.773)\end{array}$ & & $\begin{array}{c}0.076 \\
(0.472)\end{array}$ & & $\begin{array}{l}0.063 * \\
(1.939)\end{array}$ & & $\begin{array}{c}0.018 \\
(0.746)\end{array}$ & \\
\hline BETA & $\begin{array}{c}0.001 \\
(0.695)\end{array}$ & & $\begin{array}{c}0.001 \\
(0.794)\end{array}$ & & $\begin{array}{c}0.001 \\
(0.682)\end{array}$ & & $\begin{array}{c}-0.001 \\
(-0.427)\end{array}$ & & $\begin{array}{c}0.000 \\
(0.099)\end{array}$ & \\
\hline SIZE & $\begin{array}{c}-0.001 \\
(-0.930)\end{array}$ & $\begin{array}{l}-0.003 * \\
(-1.716)\end{array}$ & $\begin{array}{l}-0.000 \\
(-0.871)\end{array}$ & $\begin{array}{l}-0.003 * \\
(-1.768)\end{array}$ & $\begin{array}{c}-0.001 \\
(-1.019)\end{array}$ & $\begin{array}{l}-0.003 * \\
(-1.841)\end{array}$ & $\begin{array}{c}-0.000 \\
(-0.884)\end{array}$ & $\begin{array}{c}-0.004 * * \\
(-2.252)\end{array}$ & $\begin{array}{c}-0.001 \\
(-1.162)\end{array}$ & $\begin{array}{c}-0.003 * * \\
(-2.048)\end{array}$ \\
\hline BTM & $\begin{array}{c}0.011 * * * \\
(4.625)\end{array}$ & & $\begin{array}{c}0.012 * * * \\
(4.664)\end{array}$ & & $\begin{array}{c}0.011 * * * \\
(4.579)\end{array}$ & & $\begin{array}{c}0.012 * * * \\
(4.683)\end{array}$ & & $\begin{array}{c}0.012 * * * \\
(4.511)\end{array}$ & \\
\hline LEV & $\begin{array}{c}0.007 * * \\
(2.326)\end{array}$ & $\begin{array}{c}-0.011 \\
(-1.225)\end{array}$ & $\begin{array}{c}0.007 * * \\
(2.385)\end{array}$ & $\begin{array}{c}-0.010 \\
(-1.141)\end{array}$ & $\begin{array}{c}0.007 * * \\
(2.358)\end{array}$ & $\begin{array}{c}-0.010 \\
(-1.132)\end{array}$ & $\begin{array}{c}0.007 * * \\
(2.525)\end{array}$ & $\begin{array}{c}-0.006 \\
(-0.659)\end{array}$ & $\begin{array}{c}0.008 * * * \\
(2.861)\end{array}$ & $\begin{array}{c}-0.005 \\
(-0.551)\end{array}$ \\
\hline LTG & $\begin{array}{c}0.088 * * * \\
(10.787)\end{array}$ & & $\begin{array}{c}0.087 * * * \\
(10.759)\end{array}$ & & $\begin{array}{c}0.086 * * * \\
(10.709)\end{array}$ & & $\begin{array}{c}0.082 * * * \\
(10.973)\end{array}$ & & $\begin{array}{c}0.090 * * * \\
(12.153)\end{array}$ & \\
\hline DISP & $\begin{array}{c}-0.013 \\
(-1.623)\end{array}$ & & $\begin{array}{c}-0.012 \\
(-1.554)\end{array}$ & & $\begin{array}{c}-0.012 \\
(-1.630)\end{array}$ & & $\begin{array}{l}-0.014^{*} \\
(-1.848)\end{array}$ & & $\begin{array}{l}-0.016^{*} \\
(-1.941)\end{array}$ & \\
\hline ICC & & $\begin{array}{c}-0.772 * * * \\
(-3.946)\end{array}$ & & $\begin{array}{c}-0.817 * * * \\
(-4.165)\end{array}$ & & $\begin{array}{c}-0.846 * * * \\
(-4.340)\end{array}$ & & $\begin{array}{c}-1.079 * * * \\
(-5.367)\end{array}$ & & $\begin{array}{c}-0.887 * * * \\
(-4.454)\end{array}$ \\
\hline ROA & & $\begin{array}{c}-0.034 * * \\
(-2.329)\end{array}$ & & $\begin{array}{c}-0.034 * * \\
(-2.318)\end{array}$ & & $\begin{array}{c}-0.033 * * \\
(-2.266)\end{array}$ & & $\begin{array}{c}-0.026 \\
(-1.519)\end{array}$ & & $\begin{array}{c}-0.021 \\
(-1.156)\end{array}$ \\
\hline Constant & $\begin{array}{c}0.052 * * * \\
(6.827)\end{array}$ & $\begin{array}{c}0.039 \\
(1.501)\end{array}$ & $\begin{array}{c}0.052 * * * \\
(6.835)\end{array}$ & $\begin{array}{c}0.042 \\
(1.637)\end{array}$ & $\begin{array}{c}0.053 * * * \\
(7.024)\end{array}$ & $\begin{array}{l}0.046^{*} \\
(1.773)\end{array}$ & $\begin{array}{c}0.054 * * * \\
(7.894)\end{array}$ & $\begin{array}{l}0.065 * * \\
(2.466)\end{array}$ & $\begin{array}{c}0.054 * * * \\
(7.714)\end{array}$ & $\begin{array}{l}0.047^{*} \\
(1.788)\end{array}$ \\
\hline Industry FE & NO & YES & NO & YES & NO & YES & NO & YES & NO & YES \\
\hline Year FE & YES & YES & YES & YES & YES & YES & YES & YES & YES & YES \\
\hline Observations & 2,006 & 2,006 & 2,006 & 2,006 & 2,006 & 2,006 & 2,006 & 2,006 & 2,006 & 2,006 \\
\hline F-test & 16.78 & 16.36 & 16.46 & 16.43 & 16.34 & 16.41 & 29.74 & 17.04 & 27.48 & 16.13 \\
\hline $\mathrm{P}$-value & 0.00 & 0.00 & 0.00 & 0.00 & 0.00 & 0.00 & 0.00 & 0.00 & 0.00 & 0.00 \\
\hline
\end{tabular}

This table reports 3SLS regressions results for controversial industry sectors and control variables over 1991 to 2012 period. The dependant variables are the average implied cost of equity (ICC) and CSR score (CSR) respectively in the first and the second equation of each system. ICC is obtained from five models: Appendix B provides details on the implementation of the five models. The dummies for controversial sectors are: alcohol (ALC), tobacco (TOB), gambling (GAM), the military (MIL), firearms (FIR), cement (CEM), oil (OIL), biotech (BIO), sin industry sectors (alcohol-Tobacco-Gambling) and NonSin (military, firearms, cement, oil and biotech). BETA is beta estimated using the market model; SIZE: firm' size measured as the natural logarithm of total assets; BTM: Firm' book-to-market ratio; LEV is the leverage and computed as the ratio of total debt to the market value of equity; DISP is the forecast dispersion measured as the coefficient of variation of 1-year-ahead earnings forecasts; LTG is the consensus long-term growth forecast and ROA is firm's earning before interests and taxes on lagged total assets Appendix A provides the list of SIC and NAICS codes for controversial industry sectors. The unreported industry controls are based on the Fama and French (1997) industry classification. All the continuous variables are winsorized at the first and the $99^{\text {th }}$ percentile. ${ }^{* * *},{ }^{* *},{ }^{*}$ indicate significance at the $1 \%, 5 \%$ and $10 \%$ levels, respectively. 
Table 5: Corporate social responsibility and alternative cost of equity capital in controversial industry sectors

\begin{tabular}{|c|c|c|c|c|c|c|c|c|c|}
\hline & \multirow[b]{2}{*}{ System 1} & \multicolumn{8}{|c|}{ Model with interaction in ICC equation between CSR and dummy variable } \\
\hline & & $\begin{array}{c}\text { System } 2 \\
\text { ALC }\end{array}$ & $\begin{array}{c}\text { System } 3 \\
\text { TOB }\end{array}$ & $\begin{array}{c}\text { System } 4 \\
\text { GAM }\end{array}$ & $\begin{array}{c}\text { System } 5 \\
\text { MIL }\end{array}$ & $\begin{array}{c}\text { System } 6 \\
\text { FIR }\end{array}$ & $\begin{array}{c}\text { System } 7 \\
\text { CEM }\end{array}$ & $\begin{array}{c}\text { System } 8 \\
\text { OIL }\end{array}$ & $\begin{array}{c}\text { System } 9 \\
\text { BIO }\end{array}$ \\
\hline CSR & $\begin{array}{c}-0.173 * * * \\
(-5.594)\end{array}$ & $\begin{array}{c}-0.109 * * * \\
(-3.510)\end{array}$ & $\begin{array}{c}-0.170 * * * \\
(-5.496)\end{array}$ & $\begin{array}{c}-0.190 * * * \\
(-6.810)\end{array}$ & $\begin{array}{c}-0.180 * * * \\
(-5.476)\end{array}$ & $\begin{array}{c}-0.172 * * * \\
(-5.341)\end{array}$ & $\begin{array}{c}-0.180 * * * \\
(-5.774)\end{array}$ & $\begin{array}{c}-0.240 * * * \\
(-7.120)\end{array}$ & $\begin{array}{c}-0.153 * * * \\
(-6.535)\end{array}$ \\
\hline CSR*Dummy & & $\begin{array}{l}-0.066^{*} \\
(-1.827)\end{array}$ & $\begin{array}{c}-0.078 * * \\
(-2.393)\end{array}$ & $\begin{array}{c}0.042 \\
(0.957)\end{array}$ & $\begin{array}{c}-0.012 \\
(-0.298)\end{array}$ & $\begin{array}{c}-0.055 \\
(-0.907)\end{array}$ & $\begin{array}{c}0.079 \\
(0.508)\end{array}$ & $\begin{array}{c}0.065 * * \\
(2.077)\end{array}$ & $\begin{array}{c}0.021 \\
(0.878)\end{array}$ \\
\hline BETA & $\begin{array}{c}0.002 \\
(0.947)\end{array}$ & $\begin{array}{c}0.002 \\
(1.096)\end{array}$ & $\begin{array}{c}0.001 \\
(0.876)\end{array}$ & $\begin{array}{c}0.001 \\
(0.609)\end{array}$ & $\begin{array}{c}0.002 \\
(0.949)\end{array}$ & $\begin{array}{c}0.002 \\
(1.046)\end{array}$ & $\begin{array}{c}0.002 \\
(0.930)\end{array}$ & $\begin{array}{c}-0.000 \\
(-0.173)\end{array}$ & $\begin{array}{c}0.001 \\
(0.383)\end{array}$ \\
\hline SIZE & $\begin{array}{c}-0.000 \\
(-0.425)\end{array}$ & $\begin{array}{c}0.000 \\
(0.042)\end{array}$ & $\begin{array}{c}-0.000 \\
(-0.652)\end{array}$ & $\begin{array}{c}-0.000 \\
(-0.491)\end{array}$ & $\begin{array}{c}-0.000 \\
(-0.451)\end{array}$ & $\begin{array}{c}-0.000 \\
(-0.381)\end{array}$ & $\begin{array}{c}-0.000 \\
(-0.537)\end{array}$ & $\begin{array}{c}-0.000 \\
(-0.234)\end{array}$ & $\begin{array}{c}-0.000 \\
(-0.649)\end{array}$ \\
\hline BTM & $\begin{array}{c}0.011 * * * \\
(4.653)\end{array}$ & $\begin{array}{c}0.013 * * * \\
(5.067)\end{array}$ & $\begin{array}{c}0.011 * * * \\
(4.533)\end{array}$ & $\begin{array}{c}0.011 * * * \\
(4.474)\end{array}$ & $\begin{array}{c}0.011 * * * \\
(4.610)\end{array}$ & $\begin{array}{c}0.011 * * * \\
(4.659)\end{array}$ & $\begin{array}{c}0.011 * * * \\
(4.560)\end{array}$ & $\begin{array}{c}0.011 * * * \\
(4.727)\end{array}$ & $\begin{array}{c}0.011 * * * \\
(4.509)\end{array}$ \\
\hline LEV & $\begin{array}{c}0.008 * * \\
(2.516)\end{array}$ & $\begin{array}{c}0.010 * * * \\
(3.479)\end{array}$ & $\begin{array}{c}0.007 * * \\
(2.495)\end{array}$ & $\begin{array}{c}0.008 * * * \\
(2.661)\end{array}$ & $\begin{array}{c}0.007 * * \\
(2.388)\end{array}$ & $\begin{array}{c}0.007 * * \\
(2.452)\end{array}$ & $\begin{array}{c}0.007 * * \\
(2.418)\end{array}$ & $\begin{array}{c}0.007 * * * \\
(2.621)\end{array}$ & $\begin{array}{c}0.008 * * * \\
(2.953)\end{array}$ \\
\hline LTG & $\begin{array}{c}0.084 * * * \\
(10.882)\end{array}$ & $\begin{array}{c}0.090 * * * \\
(12.476)\end{array}$ & $\begin{array}{c}0.080 * * * \\
(10.435)\end{array}$ & $\begin{array}{c}0.086^{* * *} \\
(11.316)\end{array}$ & $\begin{array}{c}0.084 * * * \\
(10.719)\end{array}$ & $\begin{array}{c}0.083 * * * \\
(10.712)\end{array}$ & $\begin{array}{c}0.082 * * * \\
(10.642)\end{array}$ & $\begin{array}{c}0.080 * * * \\
(11.022)\end{array}$ & $\begin{array}{c}0.087 * * * \\
(12.208)\end{array}$ \\
\hline DISP & $\begin{array}{c}-0.010 \\
(-1.368)\end{array}$ & $\begin{array}{c}-0.011 \\
(-1.339)\end{array}$ & $\begin{array}{c}-0.009 \\
(-1.286)\end{array}$ & $\begin{array}{c}-0.012 \\
(-1.533)\end{array}$ & $\begin{array}{c}-0.010 \\
(-1.356)\end{array}$ & $\begin{array}{c}-0.010 \\
(-1.287)\end{array}$ & $\begin{array}{c}-0.010 \\
(-1.371)\end{array}$ & $\begin{array}{c}-0.012 \\
(-1.611)\end{array}$ & $\begin{array}{l}-0.014 * \\
(-1.736)\end{array}$ \\
\hline Constant & $\begin{array}{c}0.049 * * * \\
(6.834)\end{array}$ & $\begin{array}{c}0.047 * * * \\
(6.974)\end{array}$ & $\begin{array}{c}0.051 * * * \\
(7.205)\end{array}$ & $\begin{array}{c}0.049 * * * \\
(7.023)\end{array}$ & $\begin{array}{c}0.049 * * * \\
(6.695)\end{array}$ & $\begin{array}{c}0.049 * * * \\
(6.699)\end{array}$ & $\begin{array}{c}0.050 * * * \\
(6.886)\end{array}$ & $\begin{array}{c}0.050 * * * \\
(7.606)\end{array}$ & $\begin{array}{c}0.051 * * * \\
(7.528)\end{array}$ \\
\hline Year FE & YES & YES & YES & YES & YES & YES & YES & YES & YES \\
\hline Observations & 2,006 & 2,006 & 2,006 & 2,006 & 2,006 & 2,006 & 2,006 & 2,006 & 2,006 \\
\hline F-test & 17.38 & 20.65 & 19.84 & 18.43 & 16.97 & 16.67 & 16.50 & 29.40 & 27.15 \\
\hline $\mathrm{P}$-value & 0.00 & 0.00 & 0.00 & 0.00 & 0.00 & 0.00 & 0.00 & 0.00 & 0.00 \\
\hline
\end{tabular}

This table reports 3SLS regressions results for controversial industry sectors and control variables over 1991 to 2012 period. The dependant variables are the average implied cost of equity (ICC) and CSR score (CSR) respectively in the first and the second equation of each system. Only the first equation is reported to save space. ICC is obtained from four models: Claus and Thomas model (2001), the Lee, Ng, and Swaminathan model (2007), the Ohlson and Juettner model (2005) and the PEG ratio model of Easton (2004). Appendix B provides details on the implementation of the models. The dummies for controversial sectors are: alcohol (ALC), tobacco (TOB), gambling (GAM), the military (MIL), firearms (FIR), cement (CEM), oil (OIL), biotech (BIO), sin industry sectors (alcohol-Tobacco-Gambling) and NonSin (military, firearms, cement, oil and biotech). BETA is beta estimated using the market model; SIZE: firm' size measured as the natural logarithm of total assets; BTM: Firm' book-to-market ratio; LEV is the leverage and computed as the ratio of total debt to the market value of equity; DISP is the forecast dispersion measured as the coefficient of variation of 1-year-ahead earnings forecasts; and LTG is the consensus long-term growth forecast. Appendix A provides the list of SIC and NAICS codes for controversial industry sectors. The unreported industry controls are based on the Fama and French (1997) industry classification. All the continuous variables are winsorized at the first and the $99^{\text {th }}$ percentile. ${ }^{* * *},{ }^{* *},{ }^{*}$ indicate significance at the $1 \%, 5 \%$ and $10 \%$ levels, respectively. 
Table 6: Alternative measure of CSR and the cost of equity capital in controversial industry sectors

\begin{tabular}{|c|c|c|c|c|c|c|c|c|c|}
\hline & \multirow[b]{2}{*}{ System 1} & \multicolumn{8}{|c|}{ Model with interaction in ICC equation between CSR and dummy variable } \\
\hline & & $\begin{array}{c}\text { System } 2 \\
\text { ALC } \\
\end{array}$ & $\begin{array}{c}\text { System } 3 \\
\text { TOB } \\
\end{array}$ & $\begin{array}{c}\text { System } 4 \\
\text { GAM }\end{array}$ & $\begin{array}{c}\text { System } 5 \\
\text { MIL } \\
\end{array}$ & $\begin{array}{c}\text { System } 6 \\
\text { FIR } \\
\end{array}$ & $\begin{array}{c}\text { System } 7 \\
\text { CEM } \\
\end{array}$ & $\begin{array}{c}\text { System } 8 \\
\text { OIL } \\
\end{array}$ & $\begin{array}{c}\text { System } 9 \\
\text { BIO }\end{array}$ \\
\hline CSR & $\begin{array}{c}-0.005^{* * *} \\
(-5.617)\end{array}$ & $\begin{array}{c}-0.003 * * * \\
(-4.095)\end{array}$ & $\begin{array}{c}-0.005 * * * \\
(-5.531)\end{array}$ & $\begin{array}{c}-0.005 * * * \\
(-6.187)\end{array}$ & $\begin{array}{c}-0.005 * * * \\
(-5.548)\end{array}$ & $\begin{array}{c}-0.005 * * * \\
(-5.452)\end{array}$ & $\begin{array}{c}-0.005 * * * \\
(-5.678)\end{array}$ & $\begin{array}{c}-0.008 * * * \\
(-5.975)\end{array}$ & $\begin{array}{c}-0.004 * * * \\
(-6.308)\end{array}$ \\
\hline CSR*Dummy & & $\begin{array}{c}-0.068 * * \\
(-2.116)\end{array}$ & $\begin{array}{c}-0.072 * * * \\
(-2.587)\end{array}$ & $\begin{array}{c}0.039 \\
(0.929)\end{array}$ & $\begin{array}{c}-0.000 \\
(-0.011)\end{array}$ & $\begin{array}{c}-0.048 \\
(-0.768)\end{array}$ & $\begin{array}{c}0.050 \\
(0.335)\end{array}$ & $\begin{array}{c}0.032 \\
(0.877)\end{array}$ & $\begin{array}{c}-0.005 \\
(-0.274)\end{array}$ \\
\hline BETA & $\begin{array}{c}0.001 \\
(0.415)\end{array}$ & $\begin{array}{c}0.001 \\
(0.654)\end{array}$ & $\begin{array}{c}0.001 \\
(0.375)\end{array}$ & $\begin{array}{c}0.001 \\
(0.301)\end{array}$ & $\begin{array}{c}0.001 \\
(0.398)\end{array}$ & $\begin{array}{c}0.001 \\
(0.476)\end{array}$ & $\begin{array}{c}0.001 \\
(0.419)\end{array}$ & $\begin{array}{c}-0.001 \\
(-0.511)\end{array}$ & $\begin{array}{c}0.000 \\
(0.017)\end{array}$ \\
\hline SIZE & $\begin{array}{c}0.000 \\
(0.805)\end{array}$ & $\begin{array}{c}0.000 \\
(0.683)\end{array}$ & $\begin{array}{c}0.000 \\
(0.610)\end{array}$ & $\begin{array}{c}0.000 \\
(0.902)\end{array}$ & $\begin{array}{c}0.000 \\
(0.826)\end{array}$ & $\begin{array}{c}0.000 \\
(0.832)\end{array}$ & $\begin{array}{c}0.000 \\
(0.780)\end{array}$ & $\begin{array}{c}0.001 \\
(1.031)\end{array}$ & $\begin{array}{c}0.000 \\
(0.741)\end{array}$ \\
\hline BTM & $\begin{array}{c}0.012 * * * \\
(4.657)\end{array}$ & $\begin{array}{c}0.013 * * * \\
(4.950)\end{array}$ & $\begin{array}{c}0.012 * * * \\
(4.615)\end{array}$ & $\begin{array}{c}0.012 * * * \\
(4.495)\end{array}$ & $\begin{array}{c}0.012 * * * \\
(4.641)\end{array}$ & $\begin{array}{c}0.012 * * * \\
(4.674)\end{array}$ & $\begin{array}{c}0.012 * * * \\
(4.621)\end{array}$ & $\begin{array}{c}0.010^{* * *} \\
(3.824)\end{array}$ & $\begin{array}{c}0.012 * * * \\
(4.515)\end{array}$ \\
\hline LEV & $\begin{array}{c}0.008 * * * \\
(2.676)\end{array}$ & $\begin{array}{c}0.009 * * * \\
(3.272)\end{array}$ & $\begin{array}{c}0.008 * * * \\
(2.640)\end{array}$ & $\begin{array}{c}0.008 * * * \\
(2.811)\end{array}$ & $\begin{array}{c}0.008 * * * \\
(2.640)\end{array}$ & $\begin{array}{c}0.008 * * * \\
(2.641)\end{array}$ & $\begin{array}{c}0.008 * * * \\
(2.647)\end{array}$ & $\begin{array}{c}0.004 \\
(1.464)\end{array}$ & $\begin{array}{c}0.008 * * * \\
(2.973)\end{array}$ \\
\hline LTG & $\begin{array}{c}0.093 * * * \\
(12.250)\end{array}$ & $\begin{array}{c}0.097 * * * \\
(13.022)\end{array}$ & $\begin{array}{c}0.090 * * * \\
(11.896)\end{array}$ & $\begin{array}{c}0.095 * * * \\
(12.461)\end{array}$ & $\begin{array}{c}0.094 * * * \\
(12.245)\end{array}$ & $\begin{array}{c}0.093 * * * \\
(12.189)\end{array}$ & $\begin{array}{c}0.093 * * * \\
(12.168)\end{array}$ & $\begin{array}{c}0.085 * * * \\
(10.841)\end{array}$ & $\begin{array}{c}0.093 * * * \\
(12.663)\end{array}$ \\
\hline DISP & $\begin{array}{l}-0.015^{*} \\
(-1.886)\end{array}$ & $\begin{array}{l}-0.015^{*} \\
(-1.772)\end{array}$ & $\begin{array}{l}-0.014 * \\
(-1.812)\end{array}$ & $\begin{array}{l}-0.016^{*} \\
(-1.932)\end{array}$ & $\begin{array}{l}-0.015^{*} \\
(-1.893)\end{array}$ & $\begin{array}{l}-0.015^{*} \\
(-1.836)\end{array}$ & $\begin{array}{l}-0.015^{*} \\
(-1.888)\end{array}$ & $\begin{array}{l}-0.017 * * \\
(-2.161)\end{array}$ & $\begin{array}{c}-0.017 * * \\
(-1.996)\end{array}$ \\
\hline Constant & $\begin{array}{c}0.047 * * * \\
(6.889)\end{array}$ & $\begin{array}{c}0.047 * * * \\
(7.014)\end{array}$ & $\begin{array}{c}0.049 * * * \\
(7.144)\end{array}$ & $\begin{array}{c}0.047 * * * \\
(6.858)\end{array}$ & $\begin{array}{c}0.047 * * * \\
(6.831)\end{array}$ & $\begin{array}{c}0.047 * * * \\
(6.824)\end{array}$ & $\begin{array}{c}0.048^{* * *} \\
(6.909)\end{array}$ & $\begin{array}{c}0.050 * * * \\
(6.766)\end{array}$ & $\begin{array}{c}0.049 * * * \\
(7.229)\end{array}$ \\
\hline Year FE & YES & YES & YES & YES & YES & YES & YES & YES & YES \\
\hline Observations & 2,006 & 2,006 & 2,006 & 2,006 & 2,006 & 2,006 & 2,006 & 2,006 & 2,006 \\
\hline F-test & 19.35 & 20.54 & 20 & 19.30 & 18.76 & 18.69 & 18.59 & 29.77 & 25.28 \\
\hline P-value & 0.00 & 0.00 & 0.00 & 0.00 & 0.00 & 0.00 & 0.00 & 0.00 & 0.00 \\
\hline
\end{tabular}

This table reports 3SLS regressions results for controversial industry sectors and control variables over 1991 to 2012 period. The dependant variables are the average implied cost of equity (ICC) and CSR score (CSR) respectively in the first and the second equation of each system. Only the first equation is reported to save space. CSR is the total sum of strengths minus the total Sum of concerns. The dummies for controversial sectors are: alcohol (ALC), tobacco (TOB), gambling (GAM), the military (MIL), firearms (FIR), cement (CEM), oil (OIL), biotech (BIO), sin industry sectors (alcohol-Tobacco-Gambling) and NonSin (military, firearms, cement, oil and biotech). BETA is beta estimated using the market model; SIZE: firm' size measured as the natural logarithm of total assets; BTM: Firm' book-to-market ratio; LEV is the leverage and computed as the ratio of total debt to the market value of equity; DISP is the forecast dispersion measured as the coefficient of variation of 1-year-ahead earnings forecasts; and LTG is the consensus long-term growth forecast. Appendix A provides the list of SIC and NAICS codes for controversial industry sectors. The unreported industry controls are based on the Fama and French (1997) industry classification. All the continuous variables are winsorized at the first and the $99^{\text {th }}$ percentile. ${ }^{* * *},{ }^{* *},{ }^{*}$ indicate significance at the $1 \%, 5 \%$ and $10 \%$ levels, respectively. 
Table 7: Instrumental variable regressions results

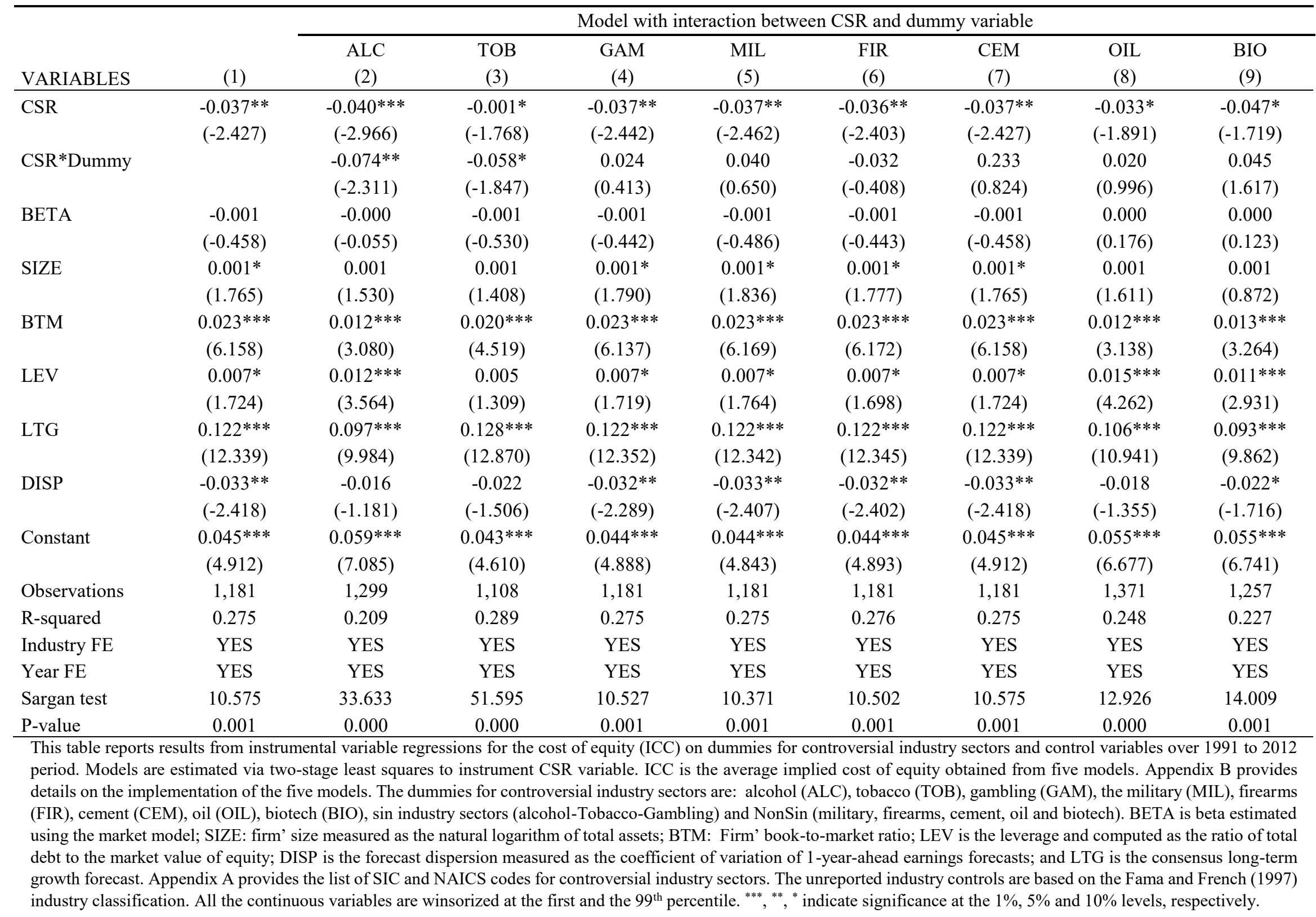




\section{Appendix A}

\section{List of SIC and NAICS codes for controversial industry sectors}

\begin{tabular}{|c|c|c|l|}
\hline $\begin{array}{c}\text { Controversial } \\
\text { industry sector }\end{array}$ & $\begin{array}{c}\text { Fama and French } \\
\text { (1997) industry } \\
\text { classification }\end{array}$ & SIC codes & \multicolumn{1}{c|}{ NAICS codes } \\
\hline Alcohol & 4 & $2100-2199$ & $\begin{array}{l}325193,4248,42481,424810, \\
42482,424820,7224,72241, \\
722410\end{array}$ \\
\hline & & $2080-2085$ & $\begin{array}{l}424940,453991,11191, \\
111910,312,3122, \\
31221,312210,31222,312221, \\
312229\end{array}$ \\
\hline Tobacco & 5 & - & $\begin{array}{l}7132,71312,713120, \\
71329,713290,72112,721120\end{array}$ \\
\hline Gambling & - & $3760-3769,3795,3480-$ & 336992 \\
\hline Military & 26 & 3489 & $332992-332994$ \\
\hline Firearms & - & - & - \\
\hline Nuclear energy & - & $3240-3241$ & - \\
\hline Cement & - & $1382,1389,2900-2912$, & - \\
\hline & & $2990-2999$ & \\
\hline Biotech & 30 & $2833-2836$ & \\
\hline
\end{tabular}

This table provides the list of SIC and NAICS codes for controversial industry sectors following Jo and $\mathrm{Na}$ (2012). 


\section{Appendix B: Alternative ICC models}

\begin{tabular}{|c|c|}
\hline \multicolumn{2}{|c|}{ Abnormal growth in earnings (AGE) models } \\
\hline $\begin{array}{l}\text { ICC model of } \\
\text { Ohlson and } \\
\text { Juettner (2005) }\end{array}$ & $\begin{array}{l}\text { The ICC is the value of } r_{O J} \text { that solves: } \\
\qquad P_{0}=\frac{d p \cdot e p s_{1}}{r_{O J}-g_{L T}}+\frac{e p s_{1} \cdot\left(g_{S T}-g_{L T}\right)}{r_{O J}\left(r_{O J}-g_{L T}\right)} \\
r_{O J}=A+\sqrt{A^{2}+\frac{e p s_{1}}{P_{0}}\left(g_{S T}-g_{L T}\right)} \\
\text { where } A=\frac{1}{2}\left(\frac{d p \cdot e p s_{1}}{P_{0}}+g_{L T}\right)\end{array}$ \\
\hline $\begin{array}{l}\text { MPEG ratio model } \\
\text { of Easton (2004) }\end{array}$ & $\begin{array}{l}\text { The ICC is the value of } r_{M P E G} \text { that solves: } \\
\qquad P_{0}=\frac{d p \cdot e p s_{1}}{r_{M P E G}}+\frac{e p s_{1} \cdot g_{S T}}{r_{M P E G}^{2}} \\
\qquad r_{M P E G}=A+\sqrt{A^{2}+\frac{e p s_{1} \cdot g_{S T}}{P_{0}}} \\
\text { where } A=\frac{1}{2}\left(\frac{d p \cdot e p s_{1}}{P_{0}}\right)\end{array}$ \\
\hline $\begin{array}{l}\text { PEG ratio model } \\
\text { of Easton (2004) }\end{array}$ & $\begin{array}{l}\text { The ICC is the value of } r_{P E G} \text { such that: } \\
\qquad r_{P E G}=\sqrt{\frac{e p s_{2}-e p s_{1}}{P_{0}}}\end{array}$ \\
\hline
\end{tabular}




\section{Appendix B: Alternative ICC models (continued)}

\begin{tabular}{|c|c|}
\hline \multicolumn{2}{|r|}{ Residual Income Valuation Models } \\
\hline $\begin{array}{l}\text { ICC model of } \\
\text { Claus and Thomas } \\
(2001)\end{array}$ & $\begin{array}{l}\text { The ICC is the value of } r_{C T} \text { that solves: } \\
P_{0}=b v_{0}+\sum_{k=1}^{5} \frac{\left(e p s_{k}-r_{C T} \cdot b v_{k-1}\right)}{\left(1+r_{C T}\right)^{k}}+\frac{\left(e p s_{5}-r_{C T} \cdot b v_{4}\right)\left(1+g_{L T}\right)}{\left(r_{C T}-g_{L T}\right)\left(1+r_{C T}\right)^{5}}\end{array}$ \\
\hline $\begin{array}{l}\text { ICC model of Lee, } \mathrm{Ng} \text {, } \\
\text { and Swaminathan } \\
\text { (2009) }\end{array}$ & 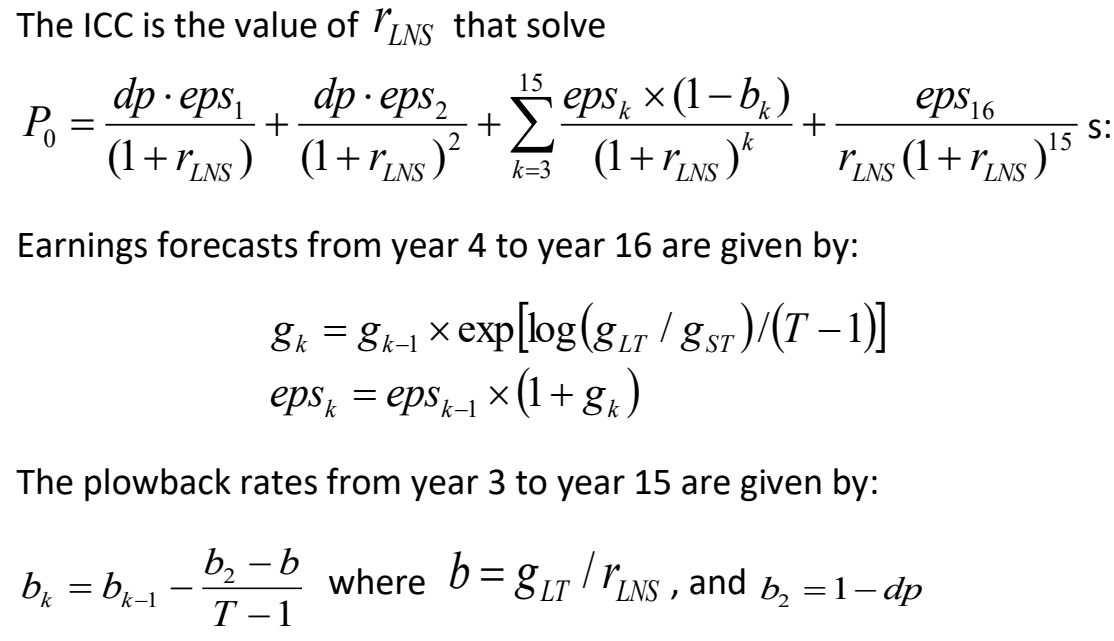 \\
\hline
\end{tabular}

\footnotetext{
Variables definition across all models:

$P_{0}$ : Firm's current stock price.

$b v_{0}$ : Book value of equity per share at the beginning of the fiscal year.

$b v_{k}$ : Expected future book value of equity per share at time $k$, where $b v_{k}=b v_{k-1}+e p s_{k}-d_{k}$ (clean surplus accounting).

$e p s_{k}$ : Expected future earnings per share for period $(k-1, k)$ using either explicit analyst forecasts or future earnings derived from growth forecasts $g_{S T}$ and $g_{L T}$, respectively. $d_{k}$ : Expected future net dividends per share for period $(k-1, k)$ computed as the dividend payout ratio $(d p)$ times the earnings per share forecast $e p s_{k}$.

$g_{S T}$ and $g_{L T}$ : Short-term or long-term future growth rate, respectively.

$R O E_{k}=e p s_{k} / b v_{k-1}$
}

To estimate the ICC from RIV models, we use a numerical (iterative) procedure that equates the right and left hand sides of the valuation equation. Solving for $r$ is equivalent to minimizing the distance between the observed stock price and the theoretical price implied by fundamentals. We stop iterating when the difference between the actual price and fitted price is within 0.001 . The numerical program requires a starting value for the ICC. We examine the sensitivity of the ICC estimates to different starting values (e.g., $10 \%$ or $20 \%$ ). The ICC estimates is restricted to be positive and set to missing otherwise. 
Appendix C: KLD's exclusionary screens description

\begin{tabular}{|c|l|}
\hline \multirow{5}{*}{ Alcohol } & - Licensing \\
& - Manufacturers \\
& - Manufacturers of Products Necessary for Production of Alcoholic \\
& Beverages \\
& - Retailers \\
& - Ownership by an Alcohol Company \\
& - Ownership of an Alcohol Company \\
& - Alcohol Other Concern (through 2002) \\
\hline \multirow{5}{*}{ Gambling } & - Licensing \\
& - Manufacturers \\
& - Owners and Operators \\
& - Supporting Products or Services \\
& - Ownership by a Gambling Company \\
& - Ownership of a Gambling Company \\
& - Gambling Other Concern (through 2002) \\
\hline \multirow{5}{*}{ Tobacco } & - Licensing \\
& - Manufacturers \\
& - Manufacturers of Products Necessary for Production of Tobacco \\
& Products \\
& - Retailers \\
& - Ownership by a Tobacco Company \\
& - Ownership of a Tobacco Company \\
- Tobacco Other Concern (through 2002)
\end{tabular}

Source: www.msci.com 